Faculty of Administration and National Security,

The Jacob of Paradies University, in Gorzów Wielkopolski,

Republic of Poland

UDK: 341.217(4-672EU):340.12 Petrażycki L.

Рад примљен: 24.09.2019.

Рад прихваћен: 17.10.2019.

\title{
EUROPEAN COHESION POLICY IN LIGHT OF LEON PETRAZYCKI'S CONCEPT OF LEGAL POLICY
}

\begin{abstract}
Leon Petrażycki's concept of legal policy, based on the author's original assumptions, focuses on the social and economic legal actions aiming to the general social prosperity. Legal policy was strictly connected with the idea of the real acceptance of the law, understood by the author as a specific socio-psychic mental state, approved in an individual experience and confirmed in a social practice. Petrażycki was the first law theorist who clearly emphasised the meaning of multiplicity of legal sources and economical nature of law, as well as the necessity to acknowledge various languages and local cultures in its contents. This concept, developed much ahead-of-its-time in the ideas of Leon Petrazycki, contains a lot of solutions which are convergent with one of the most important European policies EU cohesion policy. The objectives, assumptions and sources of cohesion policy, located at the junction of traditionally understood law-making, application of law and social and economic politics, are surprisingly similar to Petrażycki's program. The author focuses on the subject of these relations.
\end{abstract}

Keywords: Leon Petrazycki, legal policy, EU cohesion policy.

*jtjaskiewicz@hotmail.com 


\section{Introduction}

The science or practice referring to intentional and rational use of law in order to realize certain social aims would not be possible on the grounds of the views of natural law. The legal norms were given or at least discovered by the legislator, who neither created nor foresaw their long-term impact. However, the ideals expressed in the natural science (e.g. the works of Grotius, Helvetius or Montesquieu) allowed to evaluate the positive law and occasionally indicate the directions of its transformation.

The beginnings of the study of the causative, positive action of law should be sought in the Enlightenment, and the formation of the concept of rational and scientific action of law in positive philosophy. It was the positivists who claimed that the experience, science and the law were to serve the use and adaptation of the world to the will of man. Positive philosophy abandoned contemplation in favour of active action and improvement of reality and proposed a wide programme of practical actions based on systematic and scientifically verified knowledge. Like in Comte's adage - savoir pour previor, the benefits of this knowledge were to foster social progress. The society of the future was supposed to be rational and thus good and happy, as social life was supposed to be programmed and organised by science that would be objective and free from subjective restrictions.

It was especially Utilitarism that emphasised the empirical, scientific foundations of law. Thus, it was J. Bentham that is considered to be a pioneer of the concept of legal policy, as he underlined the causative and motivational functions of law in implementing the overall objective - providing maximum sum of happiness to the maximum number of people. However, it was Leon Petrazycki who is considered to be the actual founder of the concept of interdisciplinary science, comprising in its content and range nearly all significant aspects of functioning of law he specified as legal policy. Innovation and multitude of dimensions in his programme was an original, controversial and - above all - unknown phenomenon for many of his contemporaries, who functioned in different cultural or linguistic circle. It was also due to his personal and scientific peregrinations, as Petrazycki, unlike any of his contemporary prominent lawyers, had been entangled in the twists of history of the Central and Eastern Europe at the turn and early years of the 20th century (Podgorac, Petrazickis, Kojder, 2010:7 et seq.).

Petrazycki's concept, based on original and own assumptions, was ahead of its times and focused on the social, non-invasive legal actions fostering the general social prosperity. This perspective shows the convergence of the solutions proposed by Petrazycki with the EU's development policy (cohesion policy), which is one of the most important EU policies. The objectives, assumptions, sources and conditions of the EU development policy, located at the junction of tradi- 
tionally understood law-making, law application, social and economic policy, are surprisingly similar to Petrazycki's legal policy programme. The next part of this paper focuses on the subject of these relations.

\section{Assumptions and objectives of Petrazycki's legal policy}

Petrazycki's legal policy concept appeared in one of his earliest scientific works written and published in Berlin in 1893 and 1895 (Petrażycki, 1893, 1895). The analysis of the rules of the distribution of income between the owner and the bona-fide holder as well as the division of dowry under the Roman law led Petrazycki to conclude that legal regulations are strictly associated with politics and economic practice of the Roman Empire and the motivational function of law. The key to formulating the foundation of the new discipline turned out to be Petrazycki's observation that the solutions adopted by Roman legislators were solely the result of the impact of environmental phenomena or external pressure on jurisprudence and not the outcome of conscious legislation. Petrazycki, in a way reversing the perspective of the relations analysed, indicated the possibility to consciously enact such a law whose validity would produce real effects, planned and intended by the legislator: mental, social, economic or other (Kojder, 2006:338).

What is more, and proves the uniqueness and primacy of his concept, Petrazycki claimed (and aimed at proving it in his further works) that it was possible to create science whose focus would be learning all the aspects of psycho-social operation of law. According to Petrazycki, such a wide and multifaceted discipline required changes in the practice of contemporary sciences: jurisprudence, ethics, psychology, sociology and methodology. Petrazycki devoted nearly all his later works to this task.

The essence of legal policy issues, as Petrazycki wrote in "Introduction to the teachings of law and morality", was supposed to consist in "scientifically sound anticipation of the consequences to be expected in the event of the introduction of certain legal provisions and the development of rules whose introduction into the legal system would give rise to certain desired effects" (Petrażycki, 1959:13). The mission of the future science, on the other hand, was to "consciously lead humanity in the same direction which it had hitherto followed on the path of unconscious empirical adaptation, as well as to properly accelerate and rectify the pursuit of the "great luminous ideal of the future", namely "the ideal of love"(Petrażycki, 1959:16).

Petrazycki's acceptance of the psychosocial conditions of existence and operation of the law (realism, psychologism) as the foundation of his concept of law policy led him to question and reject the positivist paradigm of legal sciences, which 
required the construction of a new theory. In Petrazycki's concept, law was of substantial nature: attributive-imperative. According to Petrazycki, law and morality complemented each other, even though Petrazycki claimed that more complex nature of legal norms contributes to shaping social attitudes to a much greater extent than morality does (Babb, 1937:793). The power of motivational pressure, according to Petrazycki, stemmed from the fact that "the sense of duty of action in the human psyche was accompanied by the conviction that someone is entitled to these actions, even though they constitute realization of a duty." According to Petrazycki, this additional motivational pressure did not occur in morality, whose casual function he perceived to be of a lesser importance (Gizbert-Studnicki, Płeszka, Woleński, 2016: 556 et seq.).

From this point of view, enacting legislation with a specific content caused certain legal experience in the human psyche, which in turn resulted in the emergence of certain social attitudes and behaviours, not only individual ones. For Petrazycki, the educational function was socially integrating, allowing individuals to adapt better in the increasingly larger groups, as well as fostering cultural or civilizational progress. In such an approach to the function of the law, the legislative activity should not be limited to ordering or prohibiting such conducts, but having such influence on the addressees of the law that the implementation of the factual situation assumed by the legislator has become their preferred action due to the dispositions imprinted by law in the human psyche in various cultural conditions (Frieske, 1975:128).

Petrazycki criticised the definitions of law rejecting the classic understanding of positive law and allowing the existence and validity of law he specified as intuitive law, which - being as substantial as positive law - did not contain the image of normative facts in its content, and thus neither in the content of the psychic experience of an individual (Petrażycki, 1960:238). Petrazycki suggested the need to distinguish between official law and unofficial law in this place. In this concept, the official law was the law made and applied by the state, its bodies and institutions, as well as the law of "individuals" developed outside the scope of influence of official law (Timoshina, 2018/2:122). The official law took priority and - referring to the modern data dictionary - had stronger legal effect (Petrażycki, 1960: 302).

Petrazycki, who believed in ethical and social progress of humankind and was inspired by the theory of evolution and Darwinism, claimed that individual adaptation to life by a human being (similarly to other species) had taken place due to unconscious association of the repetitive emotions (impulses). As it is in the case of organisms avoiding harmful substances, he believed that stimulating those processes was supposed to lead to a better social adaptation of human 
beings and, consequently, progress of mankind (Gorecki, 1975:118). According to Petrazycki, the ultimate developmental aim of the human psyche was the love ideal. Similarly to Kant, or maybe Kant-inspired, Petrazycki believed in progress and solidarity of species. Thus, law making activity constituted only a measure necessary to realize the overall aim which the other, instrumental aims are subordinate to.

This process, according to Petrazycki, has so far been spontaneous, although its result was the cultural and ethical progress, different in every historical period. In Petrazycki's projection, the realization of this ideal and the eradication of individual egoisms was to result in the disappearance of legal and moral norms (Petrażycki, 1939:20). Thus, law and morality were necessary to Petrazycki only due to inadequate adaptation of human psyche to the real social relations. Hence, scientific legal policy was only to serve rationalization and acceleration of the adaptation processes in the period of transition in order to eliminate social costs of the evolution, carried out in a spontaneous manner so far (Timoshina, 2018/1:40). He emphasised at this point that the legal policy has to take into account the achieved level of social development and the legal system it is supposed to function in, thus rejecting the possibility to formulate ahistoric laws and statements.

\section{Legal policy by Leon Petrazycki vs. EU development policy}

Originality, or even oddity or utopian nature of Petrazycki' proposal, as well as first and foremost - the fact his most important works were written in Russian, contributed to the fact that his ideals were not properly recognised, even though the idea itself and the concept of legal science have been given consideration. In post-war Poland, although containing social proclamations close to socialist ideals, Petrazycki's proposals did not gain approval and were not included as part of official doctrine. This was due to the fact that the doctrine, leaving ideology aside, was based on the positivistic law understood as a standard expressed in the text, established by an entity equipped with legislative competence, subject to unconditional execution secured by a sanction. The doctrine which had been in force for years primarily emphasised the hierarchical structure of law, inseparably connected with the authorities and organisation of the state structure. In such an approach, the construction of the system of law was a direct derivative of the hierarchical structure of power and the legislative measure of the authorities which in the extreme form constitute the only normative authority.

In the hierarchical and monocentric concept of power, the rule of law policy is to be based on the creation of legal norms aimed at achieving the goals set by a rational legislator. In a typically positivistic approach, a rational lawmaker is 
a lawmaker who selects proper means for the assumed aim due to possessed knowledge and assumed preferences. In this model, the theory of application of law was of ancillary nature and was strictly correlated and subordinate to law making policy (Wróblewski 1979: 127; Wróblewski, 1985:50).

Such an approach, stemming from the traditional legal positivism, had been reinforced in the post-war period to such an extent that it also constituted the foundation of political transformations, and it seems to correspond with the common, social reception of the process of law making. Also, the doctrinal characteristics of the sources of law system expose the systematic and normative aspect of hierarchy, which in turn is related to institutionalisation and formalization of the law-making process. This hierarchical organisation of the system contains the assumption that the acts in the law of a lower degree must be included in the content of the acts in the law of a higher degree, and may not be inconsistent with them either in terms of form or content. In terms of hierarchy, the highest act in the legal system is obviously the Constitution, adopted in a special mode and, once the qualified requirements are fulfilled, providing a primary and undoubtedly the top source of law in the system's hierarchy, pursuant to the adopted assumptions.

The Polish Constitution of 1997 contained a comprehensive catalogue of the authorities entitled to make the universally binding law and the sources which this law may originate from. The constitutional reform strictly limited and classified the catalogue of sources of the universally binding law in terms of both the forms of the acts and the legislative entities, successively and hierarchically specifying them as the Constitution, ratified international agreements, legislative acts, and lower executive acts (regulations) issued for their implementation on the basis of statutory authorisation.

However, due to globalisation phenomena and the convergence of legal cultures, specifically following Poland's entry into the EU, such an approach proves inadequate or insufficient to diagnose and solve the contemporary issues. Although the concept of Montesquieu's "mouth of law" is reflected in the views of domestic legal scholars, it does not withstand rational criticism nowadays, in the era of a clash of different legal cultures in the conditions of progressive inflation of the worsening quality of written law. As the written law is unstable, all too often ambiguous and not clear enough, it is more and more difficult for the entities applying the law to refer only to the wording of the texts and the reasonableness of the actual legislator. It is currently assumed that the concept of rational legislator constitutes idealization indicating a model of institutional legislator adopted in a given culture and recreated by an interpreter - an entity applying the law pursuant to the rules adopted in the interpretation process and not the 
model originating from the actual legislator. In the face of commonly known phenomena (inflation of written law and the crisis of legislation), these patterns are increasingly determined by practice and, to the greatest extent, by doctrine and jurisprudence.

Such phenomena and the accompanying collisions or tensions result in updating at least some elements of Petrazycki's concept. The EU developmental policy was probably the most distinctive field where the classic doctrine of positive law has been tested and where new content has been assigned to Petrazycki's ideas. This policy, being one of the most significant and capacious in terms of content of the EU policies, combines the legal, economic, financial and other elements linked by a common goal - stabilization or improvement of the existing state of affairs by means of various instruments (Birkland, 2011:8). Development policy is strictly connected to the common social and economic EU ideas.

The significant features of development policy are its complexity, multimetrics and deliberateness. EU development policy refers to the social legitimization of power, consisting in communication between various entities jointly developing and implementing its aims, tasks and institutions. The instrumentalism (a characteristic feature of the previous solutions), based on social engineering and the so-called hard law, has been replaced with the quest for social justification for legislative decisions and various types of regulations included in soft law, referring to the basic principles of the functioning of the European Union: partnership, solidarity and equality.

It is characteristic for the sources and implementation of aims and instruments of the development policy to introduce - next to the classic legal solutions (statutory law) and the corresponding means or legal instruments based on the standard relation of power (administrative relation), reconciliatory solutions (agreements, contracts) applied in modern administrative models using open models of consultation and coordination (OMC) and multi-level governance (Craig, 2006:191; Hooghe, Marks, 2001:108). Some of these solutions and instruments also apply to local regulations, which means that applying law in this field requires not only dealing with difficulties characteristic for the acts of law located on the border of the EU and domestic law, as well as public and private law, but also breaking the routines and habits characteristic for the continental law doctrine.

\section{Soft law as a source and instrument of development policy compared with the continental systems}

The cohesion policy law model adopted by EU is of mixed nature (including integration and harmonisation). Integration, understood as an exclusive and 
universal nature of EU legal norms, is achieved through establishing universally binding legal acts (statutory law), developed by soft legal regulations. The European Union's development policy acts, however, contain elements that are characteristic of the harmonisation model, allowing the coexistence of two normative systems but in a non-conflicting and complementary way. The instruments playing an important role in realizing the aims of development policy and at the same time harmonization of various legal systems or doctrines is the so-called soft law. Soft law is considered to comprise the standards (norms) of conduct which are not binding in principle but may have practical effects; those are the rules and principles of conduct contained in acts which are not attributed formal and substantive binding force but which have certain (indirect) real legal effects (Snyder 1989:267; Wellens, Borchardt 1989:267). Soft law is characterized by a lower level or degree of the legal binding force than common law (statutory law) but it has a higher force than the rules which do not have a binding characteristic at all (de Melo Cartaxo, 2017).

In the EU law, the establishment and development of soft law is associated with the implementation of treaty principles, specifically the principles of subsidiarity and proportionality. The existence and effectiveness of soft law instruments lies in the fact that they can modify the operation of public institutions and bodies and thus provide a more efficient or cheaper alternative to traditional legislation. Moreover, with reference to the traditional instruments, they are less exposed to collision with the interests of a member state in the spheres considered sovereign for various non-legal reasons (Stefan, 2008: 2). In such an approach, soft law is largely based on negotiations, dialogue, facilitation, acceptance and persuasion, instead of enforcement of the law by entities equipped with formal or real instruments of power.

The concept of soft law contains the following features of policy and law, so desirable today: speed, efficiency, local and non-institutionalised initiatives, social or civic legitimacy, diversification of the sources of knowledge, effectiveness based not on coercion but acceptance or authority as the elements of a mechanism leading to a fuller and more natural participation of civil society in global governance.

In order to grasp the phenomenon of soft law, its functioning with reference to the related statutory law seems of particular importance. Hence, three functional aspects of soft law can be analysed: 1) soft law as a standard preceding establishing and functioning of the statutory law (pre-law function); 2) soft law as a normative functioning in parallel or next to the classic law making (para-law function); and 3) soft law as a standard complementing legislation (post- law function; Senden, 2004:118). 
The first of the distinguished functions is related both to the process of consultation and study of the need to perform any strictly normative (statutory) amendment and, in connection to feasibility of soft law application, in a certain way paving the road for a formal act in the law. The post law-function of law is realized through those soft-law instruments adopted in order to complement and support both primary and secondary EU law. The most innovative, however, is the para-law function of soft law, in which the soft instruments replace, rather than support, the classic law making.

Normativity and validity of soft law is a challenge for international and EU bodies and institutions, specifically the ones functioning in the continental law system (statutory law), as they do not comply with either traditional hierarchical principles of exercising public authority or with the formal legitimacy of law making. They also constitute a new situation for the model of law application, specifically judicial control, and thus indirectly for the doctrinal concept of the rule of law.

There are many acts in development policy that can be considered soft law. These are, in particular, recommendations, communications, and guidelines. Some of these acts also appear in domestic legislation. These are, for example, the partnership agreement and the guidelines and documents for the implementation of operational programmes applicable to the distribution of EU aid, the validity and application of which (also to relations other than the classical framework for the application of internal legal acts) are permitted by doctrine and jurisprudence. In doctrinal characteristics, the relation between soft law and national statutory law is based on the same assumption that is applied in the doctrine of EU law of weaker application and conditional binding force of soft law as a standard fulfilling socially useful functions, and cannot interfere axiologically, praxeologically or in terms of the content with the standards of "hard law".

It should be noted that pragmatics and flexibility of this formula, contrary to the first impression and proved by the case law, sometimes secure the situation of individuals in a better and more effective way than the statutory guarantees. This example proves the actual existence of soft law in the domestic system, as well as the classic Kelsen's constitutional formula becoming obsolete and the role of practice growing at the same time. This is due to the fact that the classic doctrine does not cope with the progressive inflation of the statutory law, increasingly casuistic in form and in many acts reminding the quality of internally binding law due to the departmental mode of development and proceeding. 


\section{Conclusions}

The concept of legal policy is based on the assumption that establishing and applying the law is a deliberate and rational activity. Leon Petrazycki, the maker of the scientific approach to this policy, believed it is possible to create law leading to effective realization of the economic and social aims assumed by the legislator. Petrazycki began the discourse on the possibility to construct the science that would formulate, organise and justify the statements or directives rationalizing and optimizing the law-making processes and law application.

In his opinion, the basis of the planned discipline was to be the fullest possible understanding of the causal action of the law. Such knowledge was supposed to constitute the basic content of that science. Legal policy, similar to other social sciences, should, as Petrazycki emphasized, accumulate the knowledge on the rules of effectiveness of predictions concerning the effects of specific law making, using empirically acquired knowledge concerning the causal and consequential action of law.

The innovative and monumental nature of Petrazycki's scientific programme was ahead of the times when the scholar worked and wrote. Although Petrazycki's ideas are over half a century away from the beginnings of European Union policies, it is astonishing how much of his thoughts can be found in the assumptions of the EU development policy. There are significant correlations between the legal assumptions and development policy. It is due to the fact that both policies are characterised by voluntarism, optimism and consideration for the complexity of the form and impact of law. The aim of both policies is to achieve the result consisting in stabilization or improvement of the existing state of social issues using the legal or economic instruments.

For Petrazycki, legal policy was a practical - not only descriptive - science. Rationality, viewed from the scientific perspective, was not only a method but the nature and destiny of human beings, who were supposed to use science in their pursuit of perfection regarding themselves and the surrounding world. Rationalization of making and applying law through scientific cognition (thus, the legal policy) was a social programme in which exposing the nature of the world through science served its positive transformation.

Petrazycki was not the only one who wished to use law for macrosocial aims. In the next decades, various ideas and programmes specified as minimalistic, non-axiological legal policy constituting an element of social engineering even gained negative meaning due to the fact that it was using law making for purposes contrary to the assumed ideas (which was especially common in totalitarian states). Such connotations were completely incongruent with Petrazycki's ideas. Policy of law, as Petrazycki understood and presented it, was connected with the 
social and individual acceptance of law, understood by the author as a certain real socio-psychic experience approved in individual experience, and confirmed on a social scale - the practice rooted in axiology. Petrazycki acknowledged and emphasised the multicentric nature of the sources of law and the necessity to acknowledge in its content (especially the so-called official law) the local cultures and the economic aspects which motivate and rationalize the law-making process.

Petrazycki's vision was never realised; however, some of its aspects and intentions are reflected in the policy perceived as certain economic, legal and social form of legal policy. Yet, while Petrazycki's aim was to build a theory of psychosocial operation of law meeting the methodological requirements of a modern scientific discipline, aimed at stimulating human actions for macrosocial purposes, the development policy is pragmatics - a set of institutional actions carried out at various levels and by various entities, using political, legal, economic and even psychological instruments sharing a certain common universal idea (either close to or convergent with Petrazycki's idea). To some extent, it is a practical answer to Petrazycki's social, humanistic programme, strongly based on economic phenomena, which was supposed to be not only scientifically developed but also practised.

The instruments of development policy that are equipped with a normative feature (soft law), not complying with the classical definition of positive law, fit well into Petrazycki's characterisation and typology of law forms. Soft law, constituting important causative instrument and the source of development policy norms, should be considered such a standard. This is because soft law is considered a phenomenon of increasing social significance, competing with or at least complying with the laws of the state. A characteristic feature of soft law is its particular flexibility and capability for environmental adaptation, thus enabling resolution of conflicts or issues in a manner adequate to the specific needs or problems.

As shown by the experience of the West European states, as well as of the United States, soft law is the result of a real dialogue to a greater extent than statutory law and, at the same time, the medium of communication between the decision-makers, law enforcement bodies (primarily the courts) and the addressees of legal norms. Without losing the substantive and formal connection with the statutory law, soft law does not constitute an independent source of law. It is realistically understood ius positivum, located between the official law and the social practice.

Positivity of soft law as a real phenomenon does not result from the fact of its establishment but, first and foremost, from its application and perception. 
The concept of validity of soft law combines the normative and realistic aspect (validity in terms of its establishment and effectiveness). Therefore, the use of soft law is decisive for its application which, leaving aside the psychologism of Petrazycki's concept, underlines the realistic dimension of the functioning of the law. Thus, soft law is characterized by reality, flexibility, pragmatics and social usefulness, as the law perhaps most fully realizing the idea of communication between the objective/normative approach to law and the institutionalised forms of law.

In this light, the actual test for the functioning of soft law is not only its normativity, assigned to statutory law, but its real social functioning. By its very nature, development policy is not strictly the domain of the legislator (or sovereign, especially the monocratic one) but a field where normativity is created mainly by consensus between the various social actors in the community, whereas its application and observance results from conviction or persuasion rather than enforcement.

Both policies assume the possibility of a cause and effect operation of law in the social space and implementation of projects on a social scale (volunteerism, social engineering) originating from the formal legislator (official law, according to Petrazycki, i.e. treaty law and statutory EU law) in the perspective of the norms assimilated and applied by individuals (intuitive law, according to Petrazycki, i.e. soft law) without the need to apply sanctions or coercion. Despite its economic and pragmatic or even consumerist direction, development policy of its source (including soft law) is permeated with Petrazycki's ideals: decline of regulations and imperative norms secured with state coercion; replacing the official law with intuitive law; general social or local practice based on useful habits stimulated or directed by motivational, pragmatic or economic costs of establishing and executing the law.

The relations between this concept and the social and economic costs of making and enforcing the law also indicate such conditions of development policy. It is widely known that conciliation mechanisms and instruments bring greater social benefits than the arguments of order and strength, especially in the long-term perspective. To a certain extent, the proposal of development policy instruments is close to the concepts based on autopoietic systems or communication concepts characteristic for the societies of mature civic democracy, where the law functions not only as an effect of instrumental and technical action but also as a process of free and equal communication between various institutions and social groups.

If the process of constitution of the development policy is perceived as a "dialogue" between the formal legislator and the addressees as entities equipped 
with communication rationality, it is soft law that constitutes an instrument of dialogue aimed at rationalisation or optimisation of assumptions and solutions adopted in the statutory law. In this vision of communication, the legal instruments of this policy cannot be perceived as an unconditional, authoritarian command to act or not to act, but as a medium by means of which conventions agreed in social dialogue are created and implemented, as modelled on the ahead-of-its-time ideas of Leon Petrazycki.

\section{References}

Babb, H.W. (1937). Petrazhitskii: Science of Legal Policy and Theory of Law. Boston University Law Review, vol. 17, pp. 793-829

Birkland, T. (2011). An Introduction to the Policy Process: Theories, Concepst and Models of Public Policy Making. M.E. Sharpe, New York

Craig, P. (2006) EU Administrative Law. Oxford University Press, Oxford, New York

Frieske, K. (1975) Leona Petrażyckiego teoria czy socjologia prawa in: Prawo w społeczeństwie, ed. J. Kurczewski, PWN, Warszawa

Gizbert-Studnicki T., Płeszka K., Woleński J. (2016). Chapter 16. 20th-Century Legal Theory and Philosophy in Poland in: A Treatiseof Legal Philosophyand General Jurisprudence. Legal Philosophy in theTwentieth Century: The Civil Law World, ed. E. Pattaro, C. Roversi, Vol. 12, Springer, Netherlands (pp. 547-586)

Gorecki, J. (1975). Social Engineering through Law in: Sociology and Jurisprudence of Leon Petrażycki, ed. J. Gorecki, Urbana (Chicago-London), University of Illinois Press, (pp. 115-132)

Hooghe, L., Marks, G. (2001). Multi-Level Governance and European Integration, Rowman \& Littlefield Publishers, Oxford

Kojder, A. (2006). Leon Petrażycki's socio-legal ideas and their contemporary continuation. in: Journal of Classical Sociology 2, No. 6, SAGE Publishing, New York, (pp. 333-358)

de Melo Cartaxo, T. (2017). Theories of Legal Sources and Soft Law: Or the Unbearable Lightness of Ought. [Electronic version] retrieved 1 September 2019 from http://ssrn.com/abstract=2940775

Petrażycki, L. $(1893,1895)$. Die Lehre wom Einkommen.Vom standpunkt des gemeinen Civilrechts unter Berücksichtigung des Entwurfs eines bürgerlichen Gesetzbuche für das Deutsche Reich, vol. 1 Berlin 1893 and vol. II Berlin 1895, H.W. Müller 
Petrażycki, L. (1939). O filozofii. Warszawa, Towarzystwo imienia Leona Petrażyckiego

Petrażycki, L., (1959). Wstęp do nauki prawa i moralności. Podstawy psychologii emocjonalnej, PWN, Warszawa

Petrażycki, L. (1960), Teoria prawa i państwa w zwiq̨zku z teoriq moralności. Tom 2, PWN, Warszawa.

Podgorac, T.I., Kojder A., Petrazickis A., (2010), Leon Petražicki, delo i rodoslov, T.I. Podgorac, Kragujevac

Senden, L. (2004). Soft law in European community law, Hart Publishing, Oxford and Portland Oregon

Snyder, F. (1993). The Effectiveness of European Community Law: Institutions, Processes, Tools and Techniques, in: Modern Law Review, No. 56, John Wiley \& Sons Ltd., London, pp. 19-54

Stefan, O.A. (2008). European Competition Soft Law in European Courts: A Matter of Hard Principles?, European Law Journal, 2008, Volume 14, Issue 6, pp. 689-877, John Wiley \& Sons Ltd. [Electronic version] retrived 1 September 2019 from http://www.ucd.ie/t4cms/08_wish_paper_Oana_Stefan.pdf

Timoshina, E.W. (Тимошина Е. В.) (2018). Философия права Л. И. Петражицкого: генезис постклассического правопонимания в российском правоведении XX в. in: Петербургская Школа Философии Права. К 150-летию со дня рождения Льва Петражицкого, eds. А. В. Поляков, Е. В. Тимошина, Издательство Санкт-Петербургского Университета, Sankt Petersburg (pp. 26-50)

Timoshina, E.W. (Тимошина E. B.) (2018). Право как справедливость: концепция интуитивного права в школе Л. И. Петражицкого in: Петербургская Школа Философии Права. К 150-летию со дня рождения Льва Петражицкого, eds. А. В. Поляков, Е. В. Тимошина, Издательство СанктПетербургского Университета, Sankt Petersburg (pp. 117-132)

Wellens, K.C., Borchardt, G.M. (1989). Soft Law in European Community Law, in: European Law Review, No. 14, Sweet \& Maxwell, UK (pp. 267-321)

Wróblewski, J. (1979). Justicication of Legal Decision, in: Revue Internationale de Philosophie, Vol. 33, No. 127/128, Belgium, (pp. 276-293); available at: https:// www.jstor.org/stable/23944028?seq=1\#page_scan_tab_contents

Wróblewski, J. (1985). Teoria racjonalnego tworzenia prawa. Zakład Narodowy im. Ossolińskich, Wrocław 


\title{
Др Јацек Јаśкиешицз,
}

Доцент,

Факултет јавне управе и националне безбедности,

Универзитет Jakub od Paradiża, Gorzów Wielkopolski, Република Пољска

\section{ЕВРОПСКА КОХЕЗИОНА ПОЛИТИКА У СВЕТЛУ КОНЦЕПТА ПРАВНЕ ПОЛИТИКЕ ЛЕОНА ПЕТРАЖИЦКОГ}

\begin{abstract}
Резиме
Концепт правне политике који је заговарао познати теоретичар права Леон Петражицки (Леон Петрад̇уцки) на почетку 20. века, заснован на оригиналним претпоставкама аутора, почива на друштвеним и економскоправним активностима које су усмерене ка постизању општег друштвеног просперитета. Правна политика била је стриктно повезана са идејом стварног прихватања закона, коју аутор схвата као специфично социопсихичко ментално стање, које је поткрепљено личним искуством и потврђено у друштвеној пракси. Петражицки је први теоретичар права који је јасно нагласио значај вишеструких правних извора и економске природе права, као и неопходност да се правним садржајима препознају и признају различити језици и локалне културе. Овај конщепт правне политике, који је далеко испред времена у коме је Петражицки живео, садржи многа конвергентна решења са једном од најважнијих европских политика - кохезионом политиком ЕУ. Циљеви, претпоставке и извори европске кохезионе политике, која представља тачку везивања између традиционално схвас́еног законодавства, примене права, и социјалне и економске политике, изненађујус́е су слични програму који је заступао Леон Петражицки. Тема овог рада је однос између ове две концепције.
\end{abstract}

Кључне речи: Леон Петражицки, концепт правне политике, кохезиона политика ЕУ. 